\title{
角形鋼管柱一水平ハンチ・変断面梁接合部の破断性状に関する実験的研究 AN EXPERIMENTAL STUDY ON FRACTURE BEHAVIOR OF HAUNCHED AND
NON-UNIFORM SECTION BEAM TO RECTANGULAR
HOLLOW SECTION COLUMN CONNECTIONS
} 杉本浩一*1, 石井 . 匠*2, 鈴木孝彦*3, 森田耕次*4 Hirokazu SUGIMOTO, Takumi ISHII, Takahiko SUZUKI and Koji MORITA

\begin{abstract}
This paper presents the results of tests on five types of beam-to-column connections. Increasing use is being made of haunched and non uniform end connections to move the plastic hinge away from column, where construction deficiencies can cause premature fracture. All five connection types tested successfully prevented premature rupture by neutralizing the negative effect of weld access holes, and exhibited large deformation capacity. However their maximum strength and plastic deformation capacity are attributed to the fracture toughness and the crystallinity of the beam materials and welds.
\end{abstract}

\begin{abstract}
Keywords: haunched beam, non-uniform section beam, beam-to-column connections, full-scale test, plastic rotation capacity, fracture behaivor

ハンチ梁、変断面梁、柱梁接合部、実大実験、塑性変形能力、破断性状
\end{abstract}

\section{1.はじめに}

ノースリッジ（1994 年）と阪神 (1995 年)の都市型大地震により 鉄骨構造に生じた重大な問題の一つは、多数の建物で生じた柱梁接 合部の脆性破断などの損傷であった1)ー4!。米国では入手できる鋼材 の材質や施工コストを勘案し、梁フランジまたはウェブを一部欠き 込んだり、梁端を鋼板やリブで補強する形式などの性能検証済ディ テールを現在採用している5)、6)。

我が国では被災した骨組全体は梁降伏形式のメカニズムを形成し ていたが、脆性破壊を防止するため、素材と溶接部に必要な勒性值 を確保し、想定する破壊の起点に許容寸法以上の切欠きが存在する 溶接を認めないことを骨子とする調查報告 ${ }^{2}$ が行われ、接合詳細 (スカラップ、組立溶接等)、入熱量や溶接材料の改善により塑性変 形能力を向上させることが提唱されている。

一方、梁の断面形状を材軸に沿って変化させることより、梁端部 の変形性能の向上を目指す接合形式が開発されている8，品。これら の形式は幅厚比 $\mathrm{b} / \mathrm{t}=5 \sim 8$ の梁フランジを対象としたものであり、 圧縮側フランジで座屈波が発生して破断を免れることが検証されて いる。梁フランジ幅厚比がさらに小さい場合梁端部形状の改善だけ では接合部の破断を防止できず、使用する鋼材や溶接部の勒性值の
影響を強く受ける。本研究は、梁端部の形状を実験变数として、 JIS- S N 鋼の下限要求勒性值を有する圧延H形鋼ならびに大入熱・ 高パス間温度を作業条件とする溶接部を用いた卜字形柱梁接合部の 実験を行い、角形鋼管柱一水平ハンチ・変断面梁接合部の耐力・塑 性変形能力および破断性状について考察している。

\section{2. 実験計画}

\section{1 試験体}

試験体はFig. 1 に示す外柱を想定したト字形柱梁接合部である。 梁は圧延 H形鋼 H - 500 × $200 \times 13 \times 24 \quad 490 \mathrm{~N} / \mathrm{mm}^{2}$ 級鋼で、柱は 冷間成形角形鋼管 $\square-400 \times 400 \times 16$ BCR295 である。試験体は 14 体である。試験体形状と溶接詳細をFig. 2 に、実験变数を Table 1に示し、試験体記号の後のカッコ内に既報の試験体名 ${ }^{10)}$ を添える。 (1) 梁端部の形状 ( 5 種類)

I : 梁端フランジの両側に添板を溶接して、水平ハンチを設ける。 II : 水平で幅方向に拡幅したダイアフラムにフランジを溶接する。 III : 通しダイアフラムを突き出し、その先に梁を混用接合する。 IV : 従来型通しダイアフラムとフランジを溶接接合する。

本論文の一部は，日本建築学会大会学術講演梗概集 構造III, pp.407 408, pp.411〜 414, 1998年に発表したものである。

*1 林相組建築事業本部生産技術部技術課 工修 Manager, Construction Technology \& Engineering.Department, Obayashi Corp.,

2 川崎製鉄(侏建材センター技術部鋼構造研究所

主任研究員・博士 (工学)

*3 新日本製鐵侏)技術開発本部鉄鋼研究所鋼構造研究開発セン

夕一主任研究員・博士 (工学)

*4 千葉大学工学部デザイン工学科 教授・博士 (工学)

M. Eng. Senior Dr. Eng.

Senior Researcher, Steel Structure Development Center, Steel Research Laboratories, Nippon Steel Corp., Dr. Eng.

Prof., Dept. of Design and Architecture, Faculty of Eng., Chiba Univ., Dr. Eng. 
Table 1 Test Specimen and Test Varables

\begin{tabular}{|c|c|c|c|c|c|}
\hline $\begin{array}{c}\text { Specimen } \\
\text { (1) }\end{array}$ & $\begin{array}{l}n \\
\text { (2) }\end{array}$ & $\begin{array}{l}\text { Detail of beam flange } \\
\text { at end connection } \\
\text { (3) }\end{array}$ & $\begin{array}{c}\text { Placement of } \\
\text { backing bars } \\
(4)\end{array}$ & $\begin{array}{c}\text { Treatment of } \\
\text { weld access hole } \\
\text { (5) } \\
\end{array}$ & $\begin{array}{c}\text { Welding } \\
\text { heat input } \\
\text { (6) }\end{array}$ \\
\hline I A45(No.4) & 2 & \multirow{2}{*}{$\begin{array}{l}\text { Wing shape of } \\
\text { beam-flange }\end{array}$} & $\begin{array}{l}\text { Continuous } \\
\text { fillet weld }\end{array}$ & \multirow{2}{*}{$\begin{array}{l}\text { Overlapped } \\
\text { in final layers }\end{array}$} & \multirow{4}{*}{$45 \mathrm{~kJ} / \mathrm{cm}$} \\
\hline I B45(No.9) & 2 & & $\begin{array}{l}\text { Tack weld } \\
\text { inside groove }\end{array}$ & & \\
\hline $1 \mathrm{C} 45$ (No.5) & 2 & $\begin{array}{l}\text { Fish tail shape of } \\
\text { through diaphragm }\end{array}$ & $\begin{array}{l}\text { Filling-up } \\
\text { fillet weld }\end{array}$ & Non-scallop & \\
\hline IIIB45(No.10) & 2 & $\begin{array}{l}\text { Short bracket shape } \\
\text { of beam }\end{array}$ & $\begin{array}{c}\text { Tack weld } \\
\text { inside groove }\end{array}$ & $\begin{array}{l}\text { Overlapped } \\
\text { in final layers }\end{array}$ & \\
\hline NA28(No.1-1) & 1 & \multirow{3}{*}{$\begin{array}{l}\text { Conventional } \\
\text { beam end }\end{array}$} & $\begin{array}{l}\text { Continuous } \\
\text { fillet weld }\end{array}$ & $\begin{array}{l}\text { Overlapped } \\
\text { in final layers }\end{array}$ & \multirow{2}{*}{$28 \mathrm{~kJ} / \mathrm{cm}$} \\
\hline IND28(No.3-4) & 1 & & $\begin{array}{l}\text { Discontinuous } \\
\text { fillet weld }\end{array}$ & $\begin{array}{l}\text { Not to be } \\
\text { overlapped }\end{array}$ & \\
\hline NB45(No.7) & 2 & & $\begin{array}{l}\text { Tack weld } \\
\text { inside groove }\end{array}$ & $\begin{array}{l}\text { Overlapped } \\
\text { in final layers }\end{array}$ & $45 \mathrm{~kJ} / \mathrm{cm}$ \\
\hline VEO(No.6) & 2 & $\begin{array}{l}\text { Extended through } \\
\text { diaphragm }\end{array}$ & $\begin{array}{l}\text { Filling-up } \\
\text { fillet weld }\end{array}$ & $\begin{array}{l}\text { Snipping } \\
\text { off fillet }\end{array}$ & $0 \mathrm{~kJ} / \mathrm{cm}$ \\
\hline
\end{tabular}

Table 3 Material Properties of Steels

\begin{tabular}{|c|c|c|c|c|c|}
\hline Element & $\begin{array}{c}\text { Thickness } \\
\begin{array}{c}(\mathrm{mm}) \\
(2)\end{array}\end{array}$ & $\begin{array}{c}\text { Yield } \\
\text { stress } \\
\left(\mathrm{N} / \mathrm{mm}^{2}\right) \\
(3)\end{array}$ & $\begin{array}{l}\text { Tensile } \\
\text { strength } \\
\left\langle\mathrm{N} / \mathrm{mm}^{2}\right\rangle\end{array}$ & $\begin{array}{l}\text { Ratio of yield to } \\
\text { tensile strength } \\
\text { (\%) } \\
\text { (5) }\end{array}$ & $\begin{array}{c}\text { Elongation } \\
(\%) \\
(6)\end{array}$ \\
\hline Beam Flange & 23.8 & 337 & 552 & 61.0 & 28 \\
\hline Web-Junction & - & 332 & 550 & 60.0 & 23 \\
\hline Beam Web & 13.0 & 383 & 559 & 68.0 & 26 \\
\hline Column Flange & 16.6 & 383 & 429 & 89.0 & 29 \\
\hline Diaphragm & 27.8 & 363 & 519 & 70.0 & 30 \\
\hline Gusset Plate & 15.6 & 348 & 526 & 66.0 & 28 \\
\hline JIS-SM490A & $16-40$ & $\geq 315$ & $490-610$ & - & $\geq 21$ \\
\hline JIS-SN 490B & $16-40$ & $325-445$ & $490-610$ & $\leq 80$ & $\geq 21$ \\
\hline
\end{tabular}
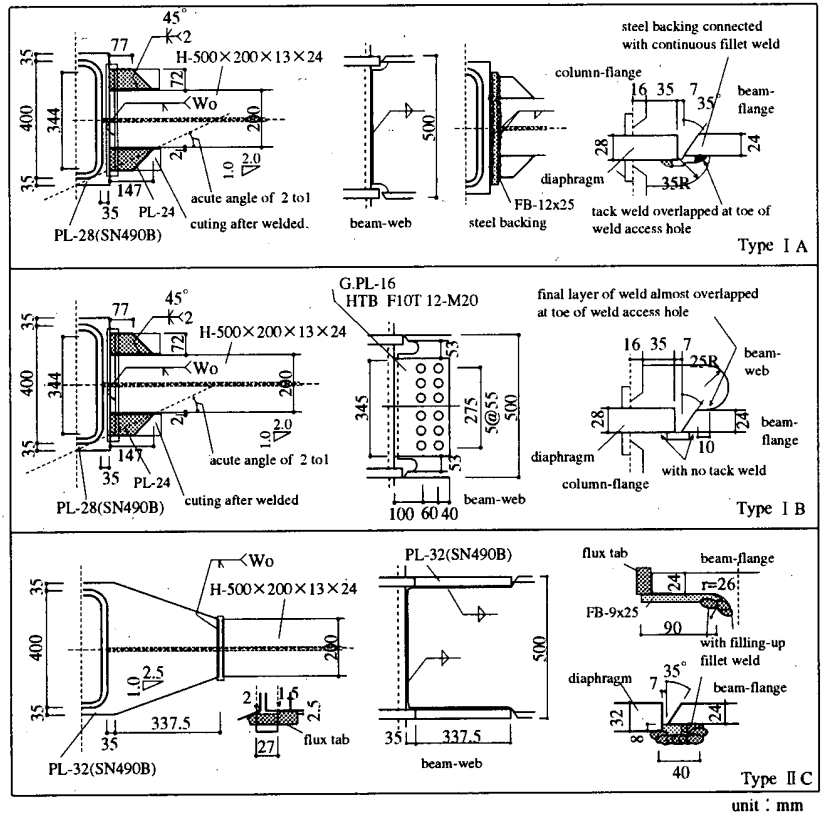

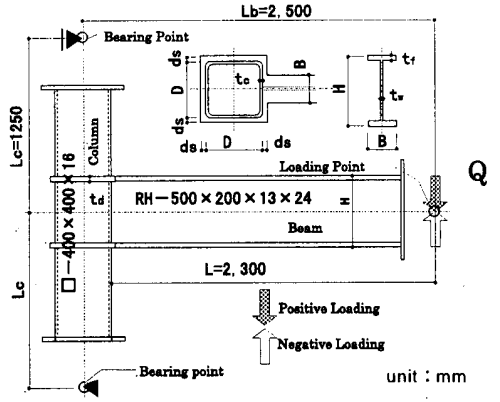

Fig. 1 Geometry of Connection Assemblage Specimen

Table 2 Chemical Composition Results and Ceq.,Pcm. Unit(\%)

\begin{tabular}{c|c|c|c|c|c|c|c|c|c|c}
$\begin{array}{c}\text { Element } \\
(1)\end{array}$ & $\mathrm{C}$ & $\mathrm{Si}$ & $\mathrm{Mn}$ & $\mathrm{P}$ & $\mathrm{S}$ & $\mathrm{Cr}$ & $\mathrm{Mo}$ & $\mathrm{Al}$ & $\mathrm{Ceq}$ & $\mathrm{Pcm}$ \\
$(2)$ & $(3)$ & $(4)$ & $(5)$ & $(6)$ & $(7)$ & $(8)$ & $(9)$ & $(10)$ & $(11)$ \\
\hline Flange $(24 \mathrm{~mm})$ & 0.21 & 0.28 & 1.19 & 0.024 & 0.013 & 0.21 & 0.09 & 0.005 & 0.49 & 0.30 \\
JIS-SM $490 \mathrm{~A}$ & $\leq 0.20$ & $\leq 0.55$ & $\leq 1.60$ & $\leq 0.035$ & $\leq 0.035$ & - & - & - & - & - \\
\hline
\end{tabular}

$\mathrm{Pcm} .=\mathrm{C}+\mathrm{S} / 30+\mathrm{Mn} / 20+\mathrm{Cu} / 20+\mathrm{Ni} / 60+\mathrm{Cr} / 20+\mathrm{Mo} / 15+\mathrm{V} / 10+5 \mathrm{~B}$

Table 4 Material Properties of Welds

\begin{tabular}{|c|c|c|c|c|c|c|}
\hline Element & \begin{tabular}{|c|} 
Diameter \\
$\phi$ \\
$(\mathrm{m})$ \\
$(2)$
\end{tabular} & $\begin{array}{c}\text { Welding } \\
\text { Heat Input } \\
(\mathrm{KJ} / \mathrm{cm}) \\
(3)\end{array}$ & $\begin{array}{c}\text { Yield stress } \\
\begin{array}{c}\left(\mathrm{N} / \mathrm{m}^{2}\right) \\
(4)\end{array} \\
\end{array}$ & $\begin{array}{c}\text { Tensile } \\
\text { strength } \\
\left(\mathrm{N} / \mathrm{mm}^{2}\right) \\
(5) \\
\end{array}$ & $\begin{array}{c}\text { Elongation } \\
(\%) \\
(6) \\
\end{array}$ & $\begin{array}{l}\mathrm{vE} 0 \\
(\mathrm{~J}) \\
(7) \\
\end{array}$ \\
\hline Wa & 1.4 & 28 & 406 & 532 & 35 & 118 \\
\hline w & & 45 & & & 20 & 109 \\
\hline YGW11 & 1.4 & $15 \sim 30$ & $\geq 390$ & $\geq 490$ & $\geq 22$ & $\geq 47$ \\
\hline
\end{tabular}

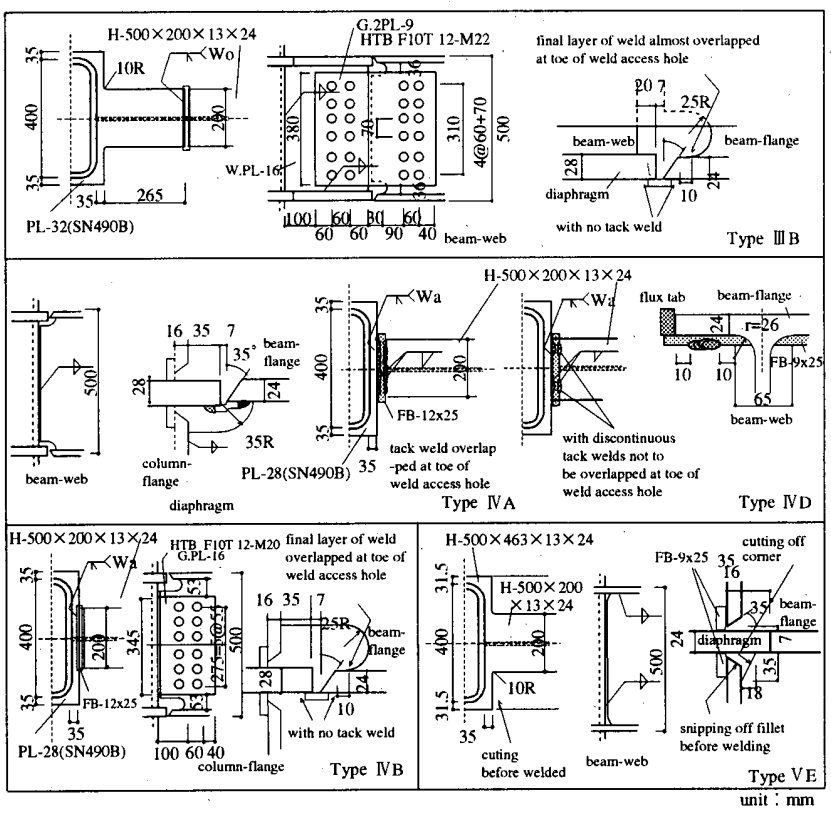

Fig.2 Details of Beam End Connection

$\mathrm{V}$ :通しダイアフラムとフランジを一体化させ、コラムを溶接する。 I の水平ハンチはハンチの角度を $1 / 2.0$ とするが、梁の全塑性曲げ モーメントの約 1.3 倍に達した時ハンチ元端がほほ全塑性状態にな るようなハンチ元幅とした。IIの水平ハンチは梁ウェブの曲げモー メントを柱管壁の面外剛性を期待しなくても、ダイアフラムとウェ ブのすみ肉溶接部での降伏せん断力による偶力に変換して伝達する ようなハンチ形状とする ${ }^{8)}$ 。正のダイアフラムは最外縁側のボルト が材軸方向 2 列並びとなる出長さとする。 $\mathrm{N}$ のウェブは溶接接合と ボルト接合の 2 種類とする。Vは幅広な圧延 $\mathrm{H}$ 形鋼のウェブを一部 削除し、コラムを挿入する。

(2) フィレット部拉よびスカラップ周辺の溶接施工 (5 種類)

$\mathrm{A}$ ：スカラップ底のフィレットに襄当て金組立溶接が重なる。

$\mathrm{B}$ ：亴当て金の組立溶接は開先内に行うが再溶融ざせる。

C：䇾当て金を分割してノンスカラップ工法で溶接する。

$\mathrm{D} ：$ フィレットのRとまりから $10 \mathrm{~mm}$ 以内に溶接しない。
E：ウェブコーナーをスニップカットして溶接する。

(3) フランジ溶接の入熱量 ( 3 種類)

0 : 溶接なし $(0 \mathrm{~kJ} / \mathrm{cm})$ 溶接を排除している。

$28: 28 \mathrm{~kJ} / \mathrm{cm}(\mathrm{Wa}):$ 最大入熱 $25 \sim 30 \mathrm{KJ} / \mathrm{cm}$ とする。

$45: 45 \mathrm{~kJ} / \mathrm{cm}$ (Wo)：最大入熱 $40 \sim 50 \mathrm{KJ} / \mathrm{cm}$ （1層 1パス溶接）とする。 試験体名称は、(1)から (3) までの実験変数で用いた記号、数値を用 いて表す。実験変数が同一で試験体が 2 体ある場合は末尾に(1)、 (2)の符号を付けて、同じ現象を説明する場合は符号を省く。

\section{2 供試材および溶接部}

レードル分析結果をTable 2 に、引張試験結果を Table 3 に、溶接部 の特性をTable 4 に、採取位置をFig. 3 に、遷移曲線をFig. 4 に、シャ ルピー值 $\mathrm{vE}$ と脆性破面率 $\mathrm{Cr}$ の関係 11 ) Fig. 5 に示す (付録 1 参照)。 （1）供試枋 梁材の C 量が規格上限值を $0.01 \%$ 超過した以外は JIS$\mathrm{S} M 490 \mathrm{~A}$ 鋼の成分規格值を満足している。Ceq 值と $\mathrm{Pcm}$ 值は各々 0.49 \%、0.30\%と高い值である。フィレットのシャルピー值 $\mathrm{vE}$ 。 $\mathrm{JIS}$ 


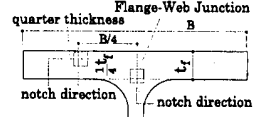

(a)

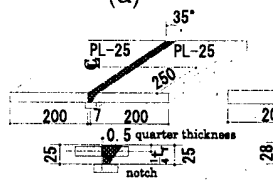

(c)

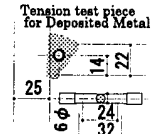

(b)

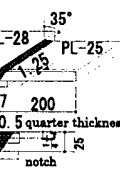

(d)

Fig.3 Sampling Location;(a)Charpy Test for Flange;(b)Tensile Test for Welds;(c) Charpy Test for HAZ at Flange;(d)Charpy Test for HAZ at Diaphragm

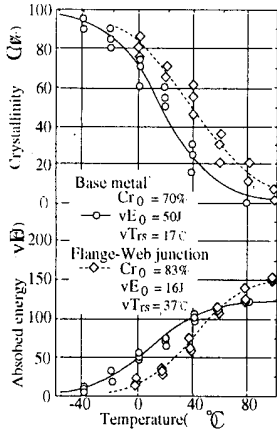

(a)

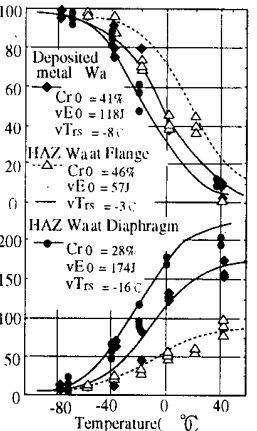

(b)

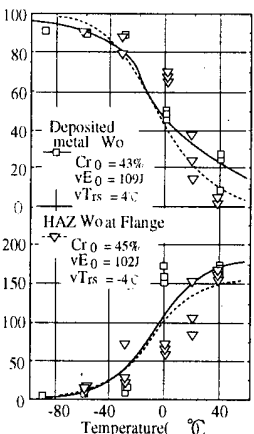

(c)
Fig.4 Charpy Test Result;(a)Flanges;(b)Heat Input $28 \mathrm{~kJ} / \mathrm{cm}$ Welds(Wa);(c) Heat Input $45 \mathrm{~kJ} / \mathrm{cm}$ Welds(Wo)

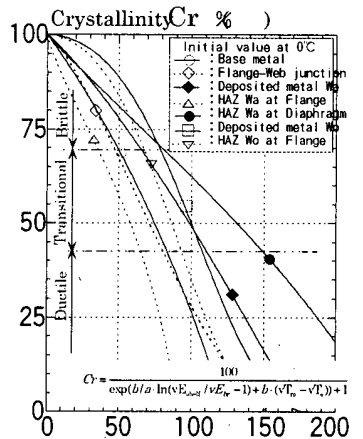

Absobed energy vE (J)

Fig. 5 Crystallinity $\mathrm{Cr}$ versus

Absorbed energy $v \mathrm{E}_{0}$ Relationships
に規定值がないが $16 \mathrm{~J}$ であり、フランジの $\mathrm{vE} 0$ の $32 \%$ になっいる。 (2) 溶接部 入熱量と強度に関して、 $45 \mathrm{~kJ} / \mathrm{cm}$ の降伏点は $28 \mathrm{~kJ} / \mathrm{cm}$ の降伏点よりも少し高いが、引張強さに差はなく、規格値を満たし ている。入熱量と勒性に関して、溶接金属では $28 \mathrm{~kJ} / \mathrm{cm} の \mathrm{vE}$ は $45 \mathrm{~kJ} / \mathrm{cm}$ の 1.1 倍であるが、梁フランジ側熱影響部では $28 \mathrm{~kJ} / \mathrm{cm}$ の $\mathrm{vE}$ は $45 \mathrm{~kJ} / \mathrm{cm}$ の 0.5 倍であり、フランジ母材とほぼ同等の值であっ た。また、ダイアフラム側熱影響部では $28 \mathrm{~kJ} / \mathrm{cm}$ の $\mathrm{vE}$ はフランジ 母材の約 3.5 倍、フィレットの 10 倍である。ダイアフラム母材の $\mathrm{vE}$ (=240J) が梁フランジ母材の 5 倍であったためと考えられる。

\section{3 載荷方法}

加力方法はFig. 1 に示すように、梁先端に繰り返しの水平力 $Q$ を 加える方法としている。載荷方法 ${ }^{12}$ は、梁端相対回転角 $\theta$ で制御す る (Fig. 6 参照)。各試験体の梁の強度・剛性はいずれも異なるが、 ${ }_{s} Q_{p}(=462 \mathrm{kN} ： \mathrm{~N}$ 試験体での梁の全塑性耐力)に対応する弾性梁端回 転角 $\theta_{p}=0.00686 \mathrm{rad}$. を基準にとり、載荷振幅を土 $2 \theta_{p} 、 \pm 4 \theta_{p} 、 \pm$ $6 \theta_{p} 、 \pm 8 \theta_{p}$ の各 2 回づつ正負交番漸増繰返し載荷する。また、梁 端部には歪を測定するための歪ゲージ、温度を測定するための熱電 対を貼付する。な押、載荷中、試験体の梁端に液化窒素を吹き付け ることにより $-4 \sim 6{ }^{\circ} \mathrm{C}$ (平均： $1{ }^{\circ} \mathrm{C}$ )に保持し、温度上昇をさせない。 試験温度はフランジ板幅の $1 / 4 \mathrm{t}$ 表側の脆性破面遷移温度 $\mathrm{vT}_{\mathrm{rs}}(=17$ $\left.{ }^{\circ} \mathrm{C}\right)$ よりも約 $16^{\circ} \mathrm{C}$ 低く、フィレットの $\mathrm{vT}_{\mathrm{rs}}\left(=37^{\circ} \mathrm{C}\right)$ よりも約 $36^{\circ} \mathrm{C}$ 低 いが、ダイアフラム側熱影響部の $\mathrm{vT}_{\mathrm{rs}}\left(=-16.3^{\circ} \mathrm{C}\right)$ よりも約 $17^{\circ} \mathrm{C}$ 高 い。Fig. 5 によれば、 $0{ }^{\circ} \mathrm{C}$ に関して、フィレット、フランジ側Wa 熱 影響部、フランジ母材、フランジ側Wo 熱影響部は $\mathrm{Cr}>65 \%$ であり、 脆性破壊が支配的である。一方、溶接金属Wo、ダイアフラム側Wa
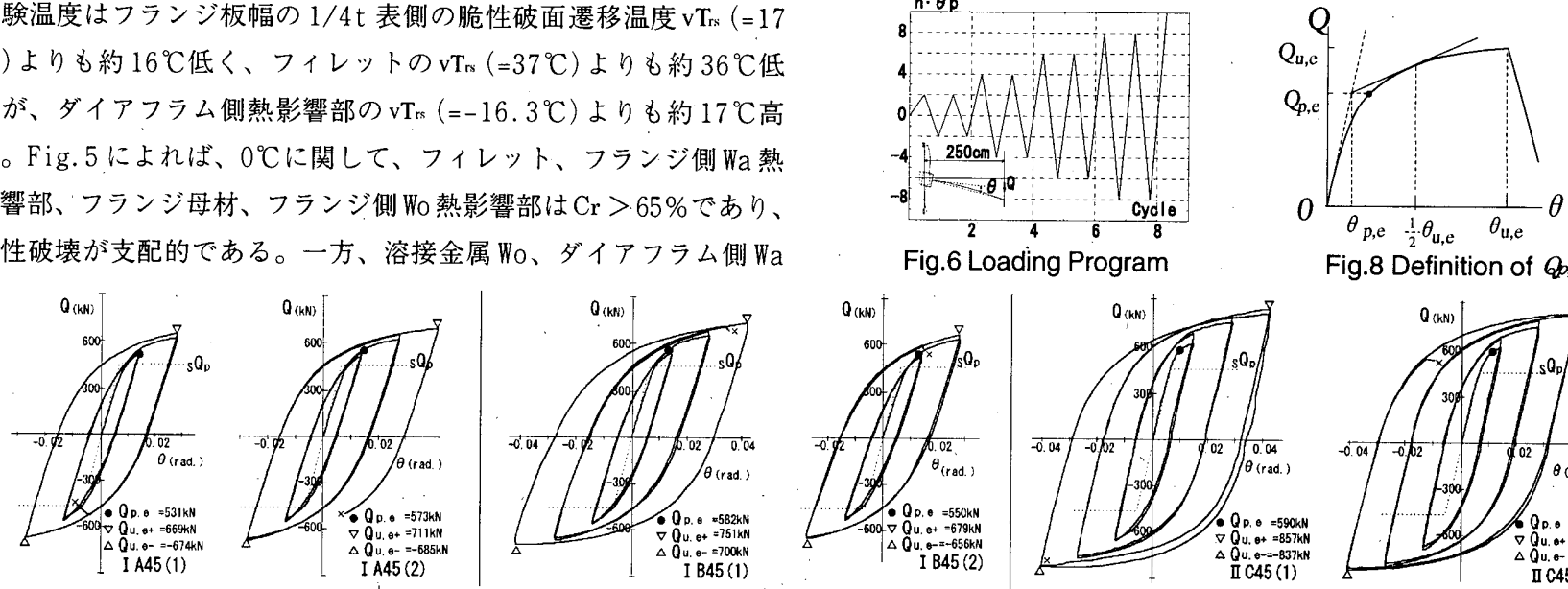

Fig.8 Definition of $Q_{p, e}$

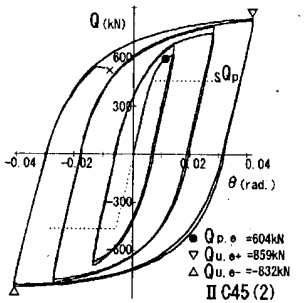

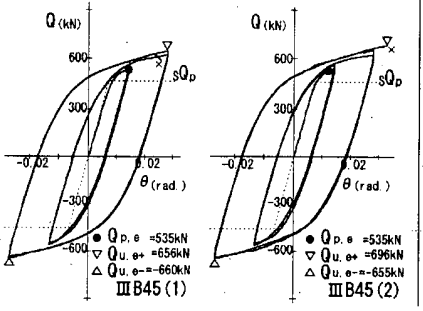
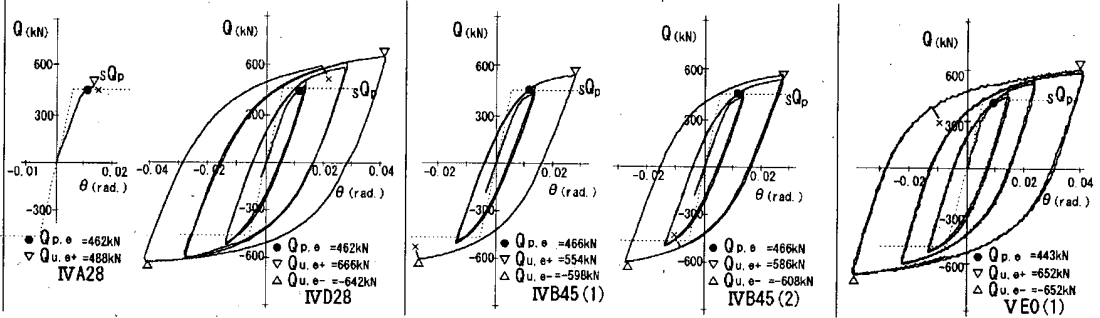

Fig.7 Hystereric Curves of Specimens 
Table 5 Summary of Test Results

\begin{tabular}{|c|c|c|c|c|c|c|c|c|c|c|c|c|c|c|c|c|c|c|c|c|c|c|c|c|c|}
\hline \multirow{2}{*}{ Specimen } & \multicolumn{3}{|c|}{$\begin{array}{c}\text { Modified } \\
\text { Shape } \\
\text { Factor } \\
\end{array}$} & \multicolumn{2}{|c|}{$\begin{array}{c}\text { Efficiency } \\
\text { of Flange } \\
\text { Joint }\end{array}$} & \multicolumn{2}{|c|}{$\begin{array}{c}\text { Efficiency } \\
\text { of Web } \\
\text { Joint }\end{array}$} & \multicolumn{4}{|c|}{ Analytical Strength } & \multicolumn{2}{|c|}{$\begin{array}{c}\text { Plasticity } \\
\text { Index }\end{array}$} & \multicolumn{12}{|c|}{ Experimental Result } \\
\hline & $\mathrm{D} / \mathrm{tc}$ & $\alpha$ & $\lambda$ & $.1 \gamma_{1}$ & $\mathrm{H}_{\mathrm{O}}$ & $-\gamma_{w}$ & ${ }^{H} \gamma_{N}$ & $\begin{array}{l}1 \mathrm{Qp} \\
(\mathrm{kN})\end{array}$ & $\begin{array}{l}\mathrm{HQp} \\
(\mathrm{kN})\end{array}$ & $\begin{array}{l}\mathrm{dQu} \\
(\mathrm{kN})\end{array}$ & $\begin{array}{l}\mathrm{HQu} \\
(\mathrm{kN})\end{array}$ & $\eta_{0}$ & $\eta_{\lambda}$ & I.F & $\begin{array}{l}\text { Qp,e } \\
(\mathrm{kN})\end{array}$ & $\begin{array}{l}\text { Qu,e } \\
(\mathrm{kN})\end{array}$ & $\sum_{(\mathrm{rad} .)} \theta \mathrm{pl}$ & $\eta \operatorname{ex}$ & $\begin{array}{l}\theta \max \\
(\times 0.01)\end{array}$ & T.F & L.I & $\begin{array}{l}v E \\
(d)\end{array}$ & $\begin{array}{l}\mathrm{Cr} \\
\%)\end{array}$ & $.1 \gamma \mathrm{cos}$ & II $\gamma_{\text {f.t. }}$ \\
\hline (1) & (2) & (3) & (4) & (5) & (6) & (7) & (8) & (9) & (10) & (11) & (12) & (13) & (14) & (15) & (16) & (17) & (18) & (19) & (20) & (21) & (22) & (23) & (24) & (25) & (26) \\
\hline $\begin{array}{l}\text { A45(1) } \\
\text { IA45(2) }\end{array}$ & \multirow{4}{*}{24.0} & 1.72 & 0.08 & 1.00 & 1.00 & 0.52 & 1.00 & 657 & 501 & 1041 & 799 & & \multirow[t]{2}{*}{-} & $\begin{array}{l}-4.2 \\
-6.1\end{array}$ & $\begin{array}{l}531 \\
573\end{array}$ & \begin{tabular}{|l|}
674 \\
685 \\
\end{tabular} & $\begin{array}{l}0.15 \\
0.23\end{array}$ & \begin{tabular}{|l|}
3.41 \\
4.16 \\
\end{tabular} & $\begin{array}{l}2.7 \\
4.1 \\
\end{array}$ & \begin{tabular}{|l|} 
(a) Flange-Web Junction \\
(a) Flange.WWb Junction
\end{tabular} & \begin{tabular}{|l|}
$j$ \\
$j$
\end{tabular} & $\begin{array}{l}16 \rightarrow 15 \\
16 \rightarrow 15\end{array}$ & \begin{tabular}{|l|}
$83 \rightarrow 83$ \\
$83 \rightarrow 84$
\end{tabular} & $\begin{array}{l}0.65 \\
0.66\end{array}$ & $\begin{array}{l}- \\
-\end{array}$ \\
\hline $\begin{array}{l}\text { I B45(1) } \\
\text { I B45(2) }\end{array}$ & & 1.71 & 0.08 & 1.00 & 1.00 & 0.15 & 1.00 & 645 & 501 & 997 & 799 & & & $\begin{array}{l}+6.2 \\
+6.1\end{array}$ & $\begin{array}{l}582 \\
550\end{array}$ & $\begin{array}{l}751 \\
679\end{array}$ & $\begin{array}{l}0.34 \\
0.20\end{array}$ & $\begin{array}{l}5.30 \\
3.38\end{array}$ & $\begin{array}{l}4.1 \\
2.7\end{array}$ & $\begin{array}{l}\text { (d) Deposited metal } \\
\text { (c) HAZ at Flange }\end{array}$ & $\begin{array}{l}\mathrm{H} \\
\mathrm{H}\end{array}$ & $\begin{array}{l}109 \rightarrow 100 \\
102 \rightarrow 98\end{array}$ & $\begin{array}{l}54 \rightarrow 56 \\
45 \rightarrow 48\end{array}$ & - & $\begin{array}{l}1.06 \\
0.94\end{array}$ \\
\hline $\begin{array}{l}11 \mathrm{C} 45(1) \\
11 \mathrm{C45(2)}\end{array}$ & & $2.35 \mid$ & 0.16 & 1.00 & 1.00 & $0.65 \mid$ & 1.00 & 1419 & 550 & 1,682 & 878 & & 3.74 & $\begin{array}{l}-6.2 \\
+8.1 \\
\end{array}$ & $\begin{array}{l}590 \\
604\end{array}$ & $\begin{array}{l}837 \\
859\end{array}$ & $\begin{array}{l}0.43 \\
0.44\end{array}$ & $\begin{array}{l}9.50 \\
9.26\end{array}$ & $\begin{array}{l}4.1 \\
4.1\end{array}$ & $\begin{array}{l}\text { (b) HAZ at Diaphragm } \\
\text { (d) Deposited metal }\end{array}$ & $\begin{array}{l}\mathrm{H} \\
\mathrm{H}\end{array}$ & $\begin{array}{l}174 \rightarrow 132 \\
109 \rightarrow 68\end{array}$ & $\begin{array}{l}28 \rightarrow 49 \\
54 \rightarrow 66\end{array}$ & - & $\begin{array}{l}1.15 \\
1.14\end{array}$ \\
\hline $\begin{array}{l}\text { IIIB45(1) } \\
\text { IIIB45(2) }\end{array}$ & & 1.34 & 0.13 & $|1.00|$ & 1.00 & 0.63 & 0.41 & 515 & 434 & 727 & 680 & & - & $\begin{array}{l}+6.1 \\
+6.1 \\
\end{array}$ & $\begin{array}{l}535 \\
535 \\
\end{array}$ & $\begin{array}{l}656 \\
696 \\
\end{array}$ & $\begin{array}{l}0.21 \\
0.22 \\
\end{array}$ & $\begin{array}{l}3.77 \\
5.07\end{array}$ & $\begin{array}{l}2.7 \\
3.3 \\
\end{array}$ & $\begin{array}{l}\text { (d) Deposited metal } \\
\text { (d) Deposited metal }\end{array}$ & $\begin{array}{l}\mathrm{H} \\
\mathrm{H} \\
\end{array}$ & $\begin{array}{l}109 \rightarrow 68 \\
109 \rightarrow 68 \\
\end{array}$ & $\begin{array}{l}54 \rightarrow 66 \\
54 \rightarrow 66\end{array}$ & - & $\begin{array}{l}0.99 \\
1.05 \\
\end{array}$ \\
\hline $\begin{array}{l}\text { NA28 } \\
\text { IVD28 } \\
\end{array}$ & \multirow{3}{*}{24.0} & 1.00 & - & 1.00 & - & 0.52 & - & 415 & - & 644 & - & \multirow{3}{*}{8.03} & \multirow{3}{*}{ - } & $\begin{array}{l}-2.2 \\
+6.2\end{array}$ & $\begin{array}{l}462 \\
462\end{array}$ & \begin{tabular}{|l|}
488 \\
666 \\
\end{tabular} & $\begin{array}{l}0.04 \\
0.34 \\
\end{array}$ & $\begin{array}{l}0.57 \\
4.36\end{array}$ & \begin{tabular}{|l|}
1.4 \\
4.1 \\
\end{tabular} & $\begin{array}{l}\text { (a) Flange-Web Junction } \\
\text { (b) HAZ at Diaphragm }\end{array}$ & \begin{tabular}{|l|}
$J$ \\
$\mathrm{~J}$
\end{tabular} & \begin{tabular}{|c|}
$16 \rightarrow 13$ \\
$.174 \rightarrow 150$ \\
\end{tabular} & $\begin{array}{l}83 \rightarrow 85 \\
28 \rightarrow 40\end{array}$ & $\begin{array}{l}0.77 \\
1.16 \\
\end{array}$ & - \\
\hline $\begin{array}{l}\text { IVB45(1) } \\
\text { IVB45(2) }\end{array}$ & & .00 & - & $|1.00|$ & - & 0.15 & - & 409 & - & 602 & - & & & $\begin{array}{l}-4.1 \\
-4.2\end{array}$ & $\begin{array}{l}466 \\
466\end{array}$ & $\begin{array}{l}598 \\
608\end{array}$ & $\begin{array}{l}0.12 \\
0.17\end{array}$ & $\begin{array}{l}2.80 \\
4.46\end{array}$ & $\begin{array}{l}2.8 \\
2.8\end{array}$ & $\begin{array}{l}\text { (c) HAZ at Flange } \\
\text { (d) Deposited metal }\end{array}$ & $\begin{array}{l}\mathrm{j} \\
\mathrm{j}\end{array}$ & $\begin{array}{l}102 \rightarrow 74 \\
109 \rightarrow 81\end{array}$ & $\mid \begin{array}{l}45 \rightarrow 61 \\
54 \rightarrow 63\end{array}$ & $\begin{array}{l}1.05 \\
1.09\end{array}$ & - \\
\hline $\begin{array}{l}\text { VEO (1) } \\
\text { VEO (2) }\end{array}$ & & 1.00 & - & 1.00 & - & 0.67 & - & 431 & - & 660 & - & & & $\begin{array}{l}+8.1 \\
-4.1\end{array}$ & $\begin{array}{l}443 \\
443\end{array}$ & $\begin{array}{l}652 \\
546\end{array}$ & $\begin{array}{l}0.39 \\
0.11\end{array}$ & $\begin{array}{l}7.83 \\
4.16\end{array}$ & $\begin{array}{l}4.1 \\
2.4\end{array}$ & $\begin{array}{l}\text { (e) Base Metal } \\
\text { (a) Flange-Web Junction }\end{array}$ & $\begin{array}{l}\mathrm{j} \\
\mathrm{j}\end{array}$ & $\begin{array}{l}50 \rightarrow 34 \\
16 \rightarrow 13\end{array}$ & $\begin{array}{l}70 \rightarrow 80 \\
83 \rightarrow 85\end{array}$ & $\begin{array}{l}1.06 \\
0.86\end{array}$ & - \\
\hline
\end{tabular}

I.F = Instance of failure. T.F $=$ Type of fracture pattern $\mathrm{L} . \mathrm{I}=\mathrm{L}$ (ocation of crack instability. $\mathrm{vE}=$ Charpy value near crack instability. $\mathrm{Cr}=$ Crystallaized surface ratio near crack instability J: section of is located at the column face (Refer Fig. 14). H: section $\mathrm{H}$ is located at the starting point of the haunched or the non-uniformed section

の 2 体は添板補強部を弓の字状に亀裂が伝播した。延性き裂が成長 した痕跡はない。IV A28試験体は延性き裂がわずかに成長していた。 $\mathrm{VEO}(2)$ 試験体は柱フランジ近傍で梁のフィレットへの組立溶接部 の亀裂が、ダイアフラムを経て柱フランジに貫通した。

（b）ダイアフラム側溶接熱影響部＼cjkstart溶接熱影響部が脆性破壊した。 II C45 (1)、IV D28 試験体は溶接止端部が起点であった。後者は延性 き裂が約 $17 \mathrm{~mm}$ であった。

(c) 梁フランジ側溶接熱影響部 溶接熱影響部が脆性破壊した。I B45 (2) 試験体は水平ハンチ先端のクレータ.の手直し溶接が起点で あった。IV B45 (1) 試験体は溶接止端部が起点であった。

（d）溶接金属＼cjkstart溶接金属が脆性破壊した。I B45（1）試験体はハンチ. 先端のクレータ処理が不十分なため溶接金属の凝固中にできた、欠 陥が起点であった。II C45(2) 試験体は組立溶接の止端部が起点で あった。II B45(1)、III B45 (2) 試験体はスカラップ底の溶接熱影響 部が起点であった。IV B45 (2) 試験体は初層の気孔・空隙や介在物の 周辺に水素が集積して脆化して生成した、銀点が起点であった。

(e)フランジ母材 母材が脆性破壊した。VEO (1) 試験体は溶接の ないフランジコーナー R 部のグラインダ傷が起点であった。 ひずみゲージの貼り付け位置をFig.11に示す。梁フランジの外側 で端と中央の 2 点、内側で同様に 2 点の合計 4 点(ただし、梁端部の 形状 I は6点である。）を対象に、変形の進渉に対応させて累積歪 $\varepsilon_{\text {skel }}$ の分布をFig. 12 に示す。図中に最大耐力時の值を、( )内に予歪量 ${ }_{p r e} \varepsilon_{k+r}($ 付録 2 参照) を添える。H 形断面の白抜き部分はスカラップ を、メ印は破壊起点を示し、破断パターンの記号を添える。

\section{2 実験経過}

（1）荷重変形関係 IV A28 試験体は降伏現象を一旦示すが、比較的
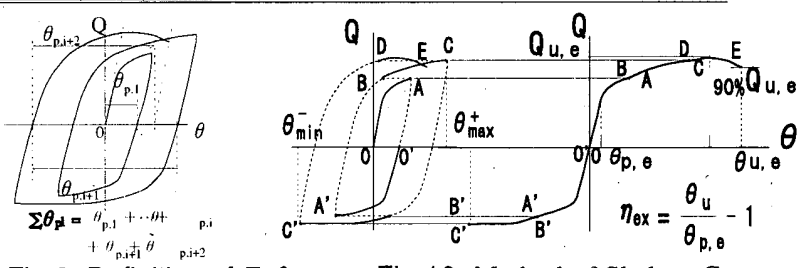

Fig.9 Definition of $\Sigma \theta p \quad$ Fig.10 Method of Skelton Curve 早期に破断した。I A45(2)、I B45(1)、II C45、IV.D28、V E0(1)試験 体は6 $\theta_{p}$ まで、I A45(1)、I B45(2)、III B45、IV B45、V E0(2)試験体は $4 \theta_{\nu}$ まで局部座屈による耐力低下はなく変形が進み、破断した。

(2) スケルトン歪と破壊パターン Fig. 12 によれば、同じ断面の 測定点のスケルトン歪 $\left(\varepsilon_{\text {stel }}\right)$ を比較すると、破断起点（×印）近傍 位置に歪が最も集中していた。 $\varepsilon_{\text {stel }}$ はウェブに欠損のある断面ではフ ランジ内側では端よりも中央で大きく、一方ウェブに欠損のない断 面では中央よりも端で大きく、またフランジに形状的な切欠きのあ る断面ではフランジ外側では中央よりも縁で大きくなる傾向がある ことがわかった。また、各試験体の破断起点の $\varepsilon_{\text {skel }}$ を比較すると、破

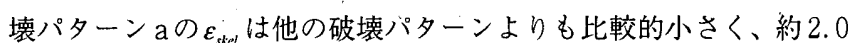
\%であった。一方破壊パターン bの $\varepsilon_{\text {stel }}$ は比較的大きく、約 $7.0 \%$ で あうた。これは、Fig. 5 にあるように、フィレット部（○印）は脆 性破壊が支配的であり、ダイアフラム側熱影響部（○印）は延性破 壊が支配的であったことと対応している。

添板を溶接した水平ハンチ試験体 4 体（2 章(1)、I A、I B ) の場 合、いずれもハンチ先端では塑性ヒンジが発生し、最大耐力時には ハンチ先端の $\varepsilon_{\text {stel }}$ はハンチ元端より大きくなり、歪はハンチ先端に 集中していた。IA45 試験体はハンチ元端のフィレット部が起点と なり破断したが、IB45 試験体は歪が集中したハンチ先端の溶接金
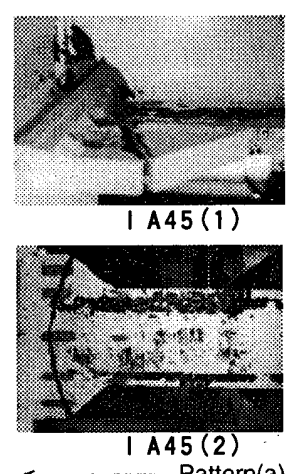

- Pattern(a)

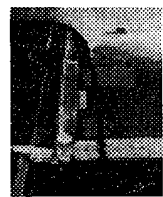

N A 28

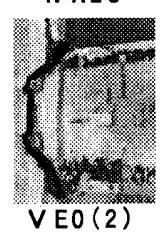

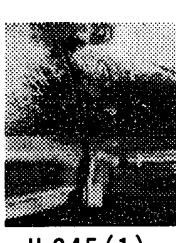

II C45(1)

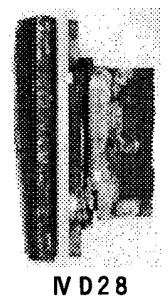

Pattern(b)
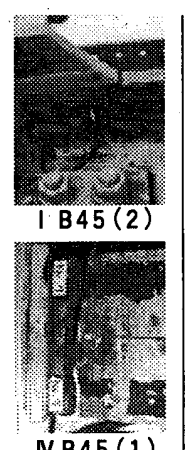

N B45(1)

Pattern(c) $\rightarrow$
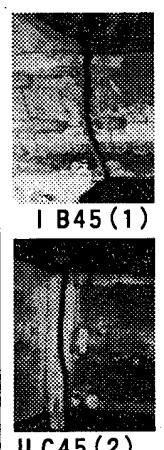
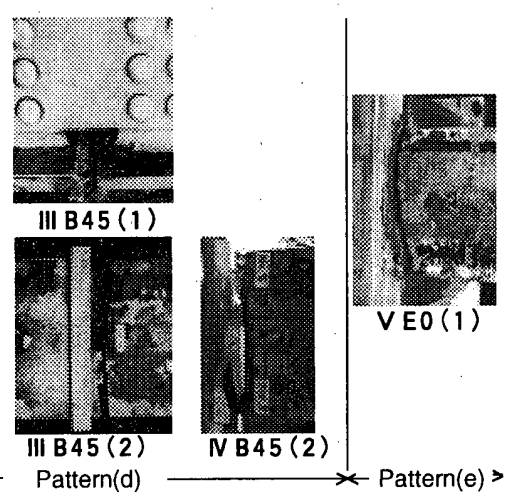

Photo 1 Extention of Yielded Zone and Fracture behavior of Flange 


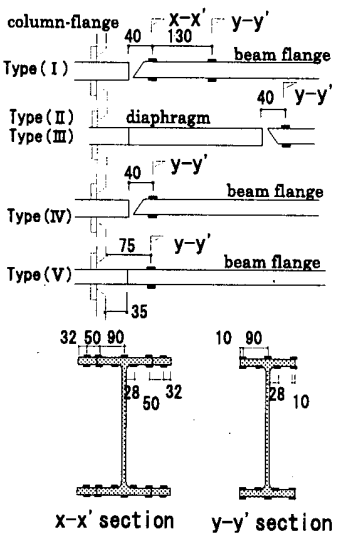

Fig.11 Location of Strain Gauges on Beam Flanges

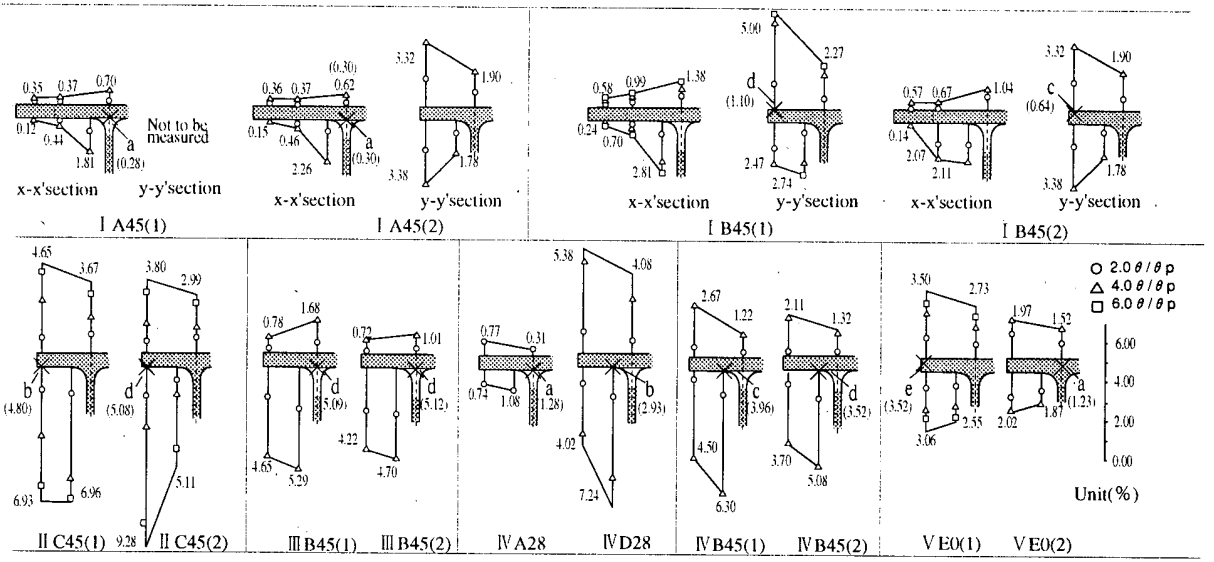

Fig.12 Strain Distribution in Flanges near Beam End and Type of Fracture Pattern
属が起点となり破断した。これは、工場溶接タイプの前者は歪が集 中するスカラップ底に組立溶接が重なり、比較的早期に脆性破壊し たのに対して、現場溶接タイプの後者はスカラップ底を梁フランジ 溶接から $10 \mathrm{~mm}$ 離していたことで、スカラップ底はハンチ先端より も脆性破壊が生じにくくなっていた。すなわち、ウェブ接合形式の 違いにより破断位置が異なったのは、溶接施工により破断危険部位 の材質変化に差が生じていたためと考えられる。よって、添板を溶 接する水平ハンチ梁接合部は、添板の溶接クレータがハンチ先端で 適切に処理されなかった場合、変形能力が低いことが確認された。 クレータ処理をハンチ先端で行わないようにすべきである。

\section{4. 水平ハンチ・変断面 $\mathrm{H}$ 形梁接合部の耐力評価}

\section{1 梁端補強部の応力分布}

柱梁接合部の応力分布をFig. 13 に示す。水平ハンチ・変断面 $\mathrm{H}$ 形梁接合部は、梁のフランジ断面積が大きくなる部分 (図中の $(\mathrm{H})$ 位置でその断面を $\mathrm{H}$ という)の境界を塑性化領域とし、元端接合部 (図中の $(\mathrm{J})$ 位置) で柱との接合断面をJとする。Fig. 14 に示す降 伏線理論 ${ }^{14)}$ に基づく評価法によれば、ウェブの接合形式によって 伝達できる曲げモーメント $\gamma_{w^{\prime}} \cdot M_{w^{p} p}$ は異なる。

1） J 断面のウェブ

${ }_{,} \gamma_{w} \cdot{ }_{j} M_{w p}=(x-S r)\left(h_{d}-x-S r\right) \cdot t_{w} \cdot w \sigma_{y}$

${ }_{,} \gamma_{w} \cdot{ }_{,} M_{w p}=\min \left(n \cdot q_{b y} \cdot R, \quad(x-S r)\left(h_{d}-x-S r\right) \cdot t_{w} \cdot w \sigma_{y}\right) \ldots$

溶接接合の場合式(4)に、ボルト接合の場合式(5)に従う。

2) H断面のウェブ

${ }_{H} \gamma_{w} \cdot{ }_{H} M_{w p}=1 / 4 \cdot h_{b}{ }^{2} \cdot t_{w} \cdot w \sigma_{v}$

${ }_{H} \gamma_{w}:{ }_{H} M_{w p}=\min \left(n \cdot q_{b y} \cdot R, 1 / 4 \cdot h_{b}{ }^{2} \cdot t_{w} \cdot w \sigma_{y}\right)$

溶接接合の場合式 (6)に、ボルト接合の場合式 (7)に従う。

ここに、, $M_{w p},{ }_{H} M_{w p}:$ 梁ウェブの全塑性モーメント、 ${ }_{j} \gamma_{w},{ }_{H} \gamma_{w}:$ 梁 ウェブの継手効率、 $x$ : 柱面の降伏域、 $S r:$ スカラップ欠損長さ、 ${ }_{w} \sigma_{y}$ : 梁ウェブの降伏点、 $n:$ 最外端のボルト本数、 $q_{b v}$ : 接合ボルト 1 本の 滑り耐力 (短期許容せん断力) 、 $R$ : 最外端ボルトの偶力腕長さであ る。

\section{2 先行降伏部位}

先行降伏の発生部位は、J 断面、 $\mathrm{H}$ 断面の全塑性曲け耐力を梁 端荷重に換算して、最小值を示す部位である。 全塑性曲げ耐力 $Q_{p}$ は、

$$
Q_{p}=\min \left({ }_{J} Q_{p},{ }_{H} Q_{p}\right)
$$

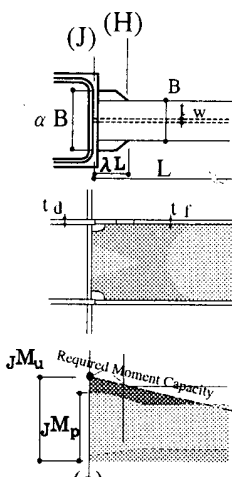

(a)

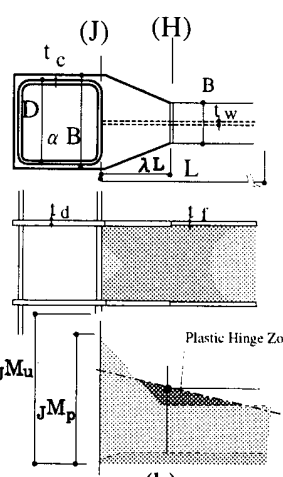

(b)

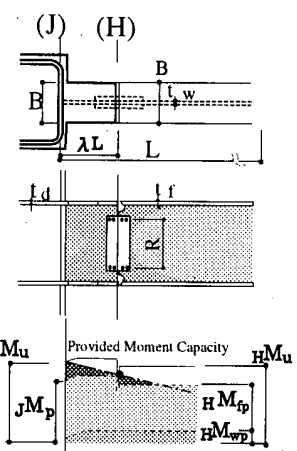

(c)
Fig.13 Variation of Moment Demand ;(a)Wing plate connection;(b) Fish tail connection;(c) Short blanket connection

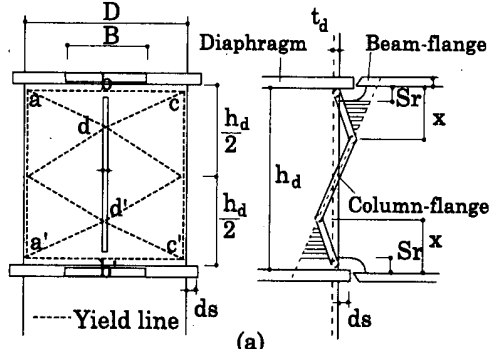

(a)

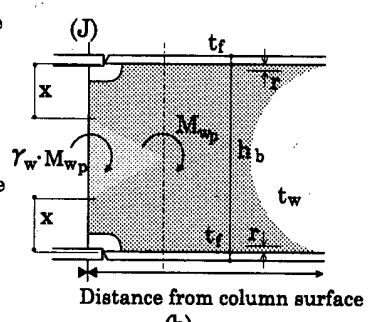

(b)
Fig.14 Mechanism of Moment Transition Area in Beam Web ;(a) Yield Line Mechanism ;(b) Moment Diagram of Beam End Connection $\left\{\begin{array}{l}{ }_{J} Q_{p} \\ { }_{H} Q_{p}\end{array}\right\}=\left\{\begin{array}{l}1 /(1-\dot{d} s / L) \cdot{ }_{J} M_{p} / L \\ 1 /(1-\lambda){ }_{H} M_{p} / L\end{array}\right\},\left\{\begin{array}{l}{ }_{j} M_{p} \\ { }_{H} M_{p}\end{array}\right\}=\left\{\begin{array}{l}{ }_{j} M_{f p}+{ }_{j} \gamma_{w} \cdot{ }_{j} M_{w p} \\ { }_{H} M_{f p}+{ }_{H} \gamma_{w} \cdot{ }_{H} M_{w p}\end{array}\right\}$ となる。ここに、ds : ダイアフラムの出長さである。, $\gamma_{w^{\prime}}, M_{w p}$ 、 ${ }_{H} \gamma_{w} \cdot{ }_{H} M_{w p}$ は、式 $(4)$ 式 $(7)$ に従う。

\section{3 最大曲げ耐力発生部位}

破断を想定した最大曲げ耐力の発生部位は、J断面、 $\mathrm{H}$ 断面の最 大曲げ耐力を梁端荷重に換算して、最小值を示す部位である。 最大曲げ耐力 $Q_{u}$ は、

$$
Q_{u}=\min \left({ }_{J} Q_{u},{ }_{H} Q_{u}\right)
$$

$\left\{\begin{array}{l}{ }_{J} Q_{u} \\ { }_{H} Q_{u}\end{array}\right\}=\left\{\begin{array}{l}1 /(1-d s / L) \cdot{ }_{J} M_{u} / L \\ 1 /(1-\lambda) \cdot{ }_{H} M_{u} / L\end{array}\right\},\left\{\begin{array}{l}{ }_{J} M_{u} \\ { }_{H} M_{u}\end{array}\right\}=\left\{\begin{array}{l}{ }_{J} \gamma_{f} \cdot{ }_{J} M_{f u}+{ }_{J} \gamma_{w} \cdot{ }_{J} M_{w p} \\ { }_{H} \gamma_{f} \cdot{ }_{H} M_{f u}+{ }_{H} \gamma_{w} \cdot{ }_{H} M_{w p}\end{array}\right\}$

となる。ここに、 ${ }_{J} M_{f u},{ }_{H} M_{f u}$ : 梁フランジ破断耐力、 ${ }_{d} \gamma_{f},{ }_{H} \gamma_{f}$ : 梁フラ ンジの継手効率である。

圧縮側フランジでの局部座屈が発生せず、引張側フランジが鋼材 または溶接金属の引張強さに相当する引張耐力が発揮されれば、 ${ }_{J} \gamma_{f},{ }_{H} \gamma_{f}=1.0$ として式(9) から計算される最大曲げ耐力 ${ }_{J} Q_{u}{ }_{H} Q_{u}$ が期 待できる。その ${ }_{J} Q_{u},{ }_{H} Q_{u}$ を各試験体について Table 5 に示す。 
しかしながら、J断面にはスカラップ底、喠当て金組立溶接、突 合せ溶接部が存在し、H断面には添板フランジ縁、混用接合部の断 面変化部分等が存在するため、上記の最大耐力に到達する前に、こ れらの破壊危険部位に存在する治金的な切欠きが起点となって破填 する可能性がある。石井らと鈴木らは破面観察から特定した破壊起 点近傍の勒性值 (以下、代表特性として推定シャルピー值 $v E b r$ をい う。付録 2 参照) と梁フランジの継手効率 (最大耐力実験值よりウェ ブ寄与分を除いたモーメントを、上下フランジの中心間距離と素材 引張強さによる破断耐力の積で除した比）との関係らならびに、最 大耐力実験值 ${ }_{f} P_{\text {max.e }}$ と素材引張強さによる破断耐力 ${ }_{f} P_{u}$ との比との 関係 ${ }^{16 !}$ にはともに正の相関があることを確認している。

そこで、破壊起点近傍位置の $\mathrm{vE}$ の推移と $\mathrm{Cr}$ の推移（表中の $109 \rightarrow$ 100 は載荷前後を示す。付録 2 参照) と、式(10)に従いを算定し たフランジ継手効率実験值 $\left(\gamma_{f e}:{ }_{d} \gamma_{f e} 、 H_{f e e}\right)$ をTable 5 に示す。

$$
\gamma_{f, \mathrm{e}}=\left(M_{u, e}-\gamma_{w} \cdot M_{w p}\right) / M_{f u}=\frac{{ }_{f} P_{\max , e} \cdot\left(H-t_{f}\right)}{{ }_{i} P_{u} \cdot\left(H-t_{f}\right)}=\frac{{ }_{f} P_{\max , e}}{A_{f} \cdot \sigma_{\mathrm{u}}^{*}}
$$

ここに、、 $M_{u, e}$ : 最大曲げ酎力実験值 $\left({ }_{0} M_{u, e} 、{ }_{H} M_{u, e}\right) 、 A_{r}$ ：破断した断面 積、 $\sigma_{\mathrm{u}}^{*}$ : 破断した位置 (フランジ素材、溶接金属、ダイアフラム)の 引張強さである。

\section{5. 実験結果の考察}

\section{1 梁端部の形状による奻果}

水平ハンチ・変断面試験体（2 章(1) I A、I B、II C、II B ）の降 伏耐力実験值 $Q_{p, e}(2$ 体の 平均值 $=552 \mathrm{kN} 、 566 \mathrm{kN} 、 59.7 \mathrm{kN} 、 535 \mathrm{kN})$ は従来型試験体 (2 章 (1) N A 、 N D、N B ) の 4 体の平均值 $=464 \mathrm{kN}$ ) の $1.2 \sim 1.3$ 倍であった。同様に、前者の最大耐力実験值 $Q_{u, e}$ は後 者の $1.1 \sim 1.4$ 倍であった。水平ハンチ・変断面試験体は、従来型 試験体に比べて降伏耐力および最大耐力とも向上した。これは梁端 接合部を水平ハンチや変断面にすることによる効果である。

\section{2 フィレット部および旁当て金の溶接施エによる影霎}

墨当て金組立溶接がフィレットに重なる溶接施工 (2章 $(2) 、 A)$ と したIV A28 試験体は耐力上昇推定值 $Q_{u} / Q_{p}=1.55$ というように、耐 力上昇が期待できるものであったが、結果としてスカラップ底の組 立溶接から早期に脆性破断し、 $Q_{u, e} / Q_{p, e}=1.06 、, \gamma_{f, e}=0.77$ であった。 塑性变形倍率 $\eta_{e x}=0.57$ となり変形能力は低かった。組立溶接をス カラップ底から離した溶接施工（2 章(2)、D）としたIN D28 試験体 と、ウェブ欠損部とフィレットを充填する溶接施工としたII C45 試 験体 (1)，(2)は $Q_{u} / Q_{p}=1.55 、 1.60 、 1.60$ となり、耐力上昇は十分 期待できた。結果として組立溶接からの破壊を防止でき、 ${ }_{s} \gamma_{f . e}=1.16 、{ }_{H} \gamma_{f, e}=1.15 、 1.14 、 \eta_{e x}=4.36 、 9.50 、 9.26$ となり、IV A28 試験体よりも優れた変形能力であった。よって、圧延 H形鋼梁 を用いた時スカラップ底のフィレットに裏当て金組立溶接を重畳さ せないことを施工禁止事項として守った場合、守らない場合よりも 高い変形性能が得られることがわかった。

\section{3 フランジ溶接の入熱量による影霊}

試験体全 14 体の $\eta_{e x}$ は $0.57 ９ .50$ である。溶接入熱量と $\eta_{e x}$ の関係について、入熱量が大であるWoを用いたII C45(1) 試験体は $\eta_{e x}=9.5$ で、溶接なし $(0 \mathrm{~kJ} / \mathrm{cm})$ のV E0 $(1)$ 試験体は $\eta_{e x}=7.8$ であ り、両者の梁端部の形状は大きく違うが $\eta_{e x}$ 差は小さい。また、 本試験体製作 (2.2 章 (2) 溶接部) は入熱量の大小による溶着金属
の降伏点・引張強さの影響が小さいものであった。溶着金属Woの シャルピー值は梁素材の約 1.5 倍であった。これは下向き姿勢の 全 6 層のうち、中間層 (第 2 $４$ 層 : 440Amp、40〜43V、22 $24 \mathrm{~cm}$ / $\mathrm{min}$ ) 以外を入熱量 $28 \sim 35 \mathrm{~kJ} / \mathrm{cm}$ による溶接法としたことにより、 中間層は最終層(第 5－6層)の溶接熱作用で再結晶化し、その材質 変化を和らげていたため、シャルピー值は素材く溶接金属の関係 になっていたと思われる。結果として今回の溶接法では入熱量の 大小による変形能力に及ぼす影響を確認できなかった。今後、溶 接パス間の熱影響（ぜい化と再結晶化）を検討する必要がある。

\section{4 梁接合部の耐力評価}

本実験結果と 4.3 章で述べた既往の研究 ${ }^{153}$ 、16) から、推定シャル ピー值 $v E b r$ と梁フランジの継手効率 $\gamma_{f}$ の関係を Fig. 15 に、推定脆 性破面率 $C r$ と $\gamma_{f}$ の関係を Fig. 16 に示す。本実験と文献 15 のデー 夕は付録 2 に示す予歪効果を考慮している。Fig. 15 (a) は本実験に よる、J断面のものを々（8体）で、H断面のものを゙（6体）で示 す。Fig. 15(b)は本実験のものを○（14 体)、文献 15 のものを (10体：裏当て金組立溶接の連続すみ肉溶接やスカラップ底の傷の 補修を施した通しダイアフラム形式・柱梁接合部の繰返し載荷実 験によるもので、本実験と重複する 4 体と溶接欠陥を有した 1 体の 計 5 体分を除外している)、文献 16 のものを口（19 体：通しダイ アフラムー梁フランジ溶接部を模した溶接欠陥付き溶接継手の単 調引張実験によるもの) で示す、計 43 体である。

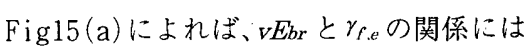

・正の相関が見られ、 $v E b r$ が $80 \mathrm{~J}$ 以上であれば、 ${ }_{j} \gamma_{f, e}$ と ${ }_{H} \gamma_{f . e}$ は 1.00 以上であった。J $\gamma_{f . e}$ と ${ }_{H} \gamma_{f . e}$ の両者間に有意差は少ない。

${ }^{v E b r}$ と ${ }_{j} \gamma_{f e}$ の相関係数は 0.805 であり、 ${ }_{H} \gamma_{f . e} よ り も$ 明確な相関性 が、広範囲の $v E b r(13 \mathrm{~J} \sim 150 \mathrm{~J})$ で見られた。

Fig15(b)、Fig16によれば、全 43 体のデータから

$\cdot v E b r$ と $\gamma_{f . e} 、 C r$ と $\gamma_{f . e}$ の関係はともに正の相関があり、相関係数は 各々 $0.741 、 0.665$ であり、 $\gamma_{f . e}$ は各々式 $(11) 、$ 式(12)で求まる。

$$
\begin{aligned}
& \gamma_{f . e}=0.842+v E_{b r} / 519(R=0.741, n=43)-----(11) \\
& \gamma_{f . e}=1.20-C r / 281(R=0.665, n=43) \quad-----(12)
\end{aligned}
$$

水平ハンチ・変断面がない梁端部の形状 (2 章(1) N、V) の試験 体 6 体は、 $Q_{p, e} / Q_{p}$ が $1.03 \sim 1.14$ であり、ウェブの継手効率 $(4.2$ 章）を考慮することで、降伏耐力実験值は， $\gamma_{f}=1.0$ と設定しても 評価值と良い対応を示している。一方、 $Q_{u, e} / Q_{u}$ は $0.76 \sim 1.03$ であ り、評価值は実験值よりも大きい。一方、式 (9)、式(10)を用いて 計算するとフランジ継手効率実験值 $\gamma_{f, e}=0.77 \sim 1.16$ であり、破 断位置近傍では $v E b r=13 \mathrm{~J} \sim 150 \mathrm{~J}$ である。表 $5(25)$ 欄の, $\gamma_{f, e}$ と (23) 欄の載荷後の $v E b r$ を比べると、各々の最低值、平均値、最高値に 対して, $\gamma_{f, e}=0.77 、 0.99 、 1.16 、 v E b r=13 \mathrm{~J} 、 61 \mathrm{~J} 、 150 \mathrm{~J}$ であり、正

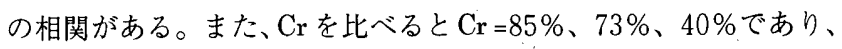
$\mathrm{Cr}$ と, $\gamma_{f . e}$ の間には負の相関がある。平均值と最高值間を補間する と、, $\gamma_{f, c} \geqq 1$ となるための条件は $v E b r 、 66 \mathrm{~J} 、 \mathrm{Cr} \leqq 67 \%$ となる。 次に、水平ハンチ・変断面試験体（2章(1) I A、I B、II C、II B) は、 $Q_{p, e} / Q_{p}=1.06 \sim 1.23$ であり、実験值は評価值より若干大きい。一 方、 $Q_{u, e} / Q_{u}=0.84 \sim 1.02$ であり、評価值は実験值よりも大きい。 式 (9)、式(10)を用いて計算すると、光 $\gamma_{f . e}=0.65 、 0.66 、{ }_{H} \gamma_{f . e}=0.94$ ～1.15であり、破断位置近傍の $v E b r$ は $15 \mathrm{~J}$ ～1 $132 \mathrm{~J}$ である。表 5 $(25)$ 欄の, $\gamma_{f, e}$ と $(26)$ 欄 $\gamma_{f, e}$ と載荷後の $v E b r$ の関係を比べると、J 


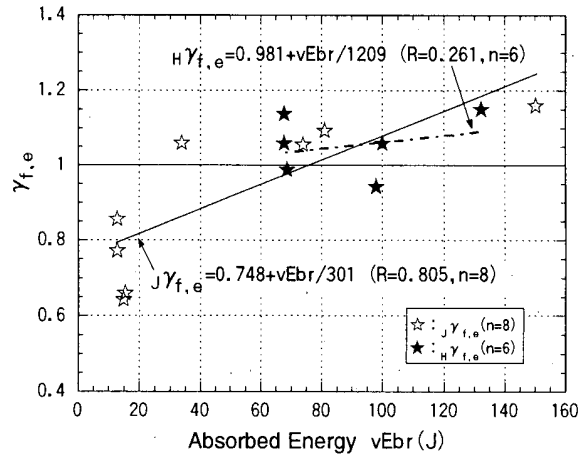

(a)

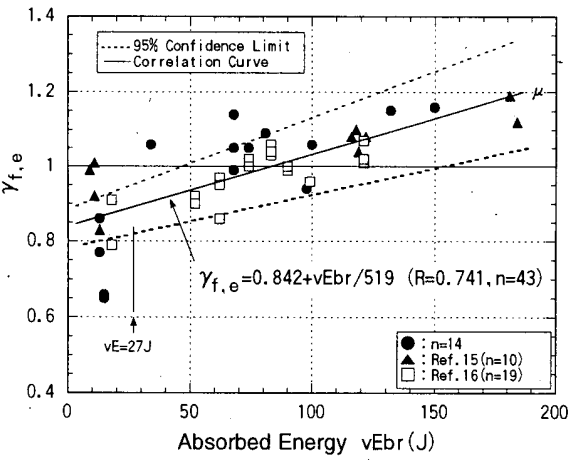

(b)

Fig.15 Variation of Strength Ratio of Flange with Absorbed Energy ;(a)Comparison ${ }_{J} \gamma_{C}$ with ${ }_{H} \gamma_{f} ;$ (b)Combination with the past data

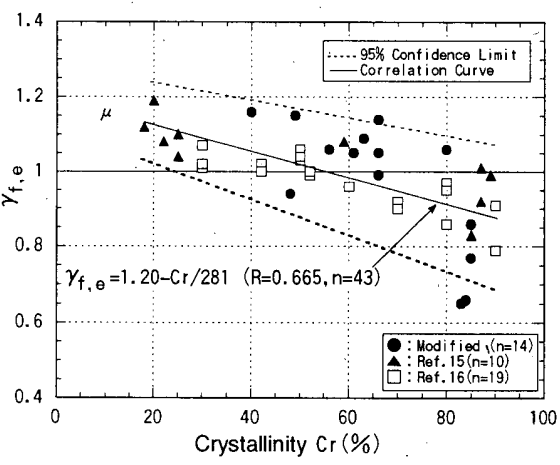

Fig.16 Variation of Strength Ratio of Flange with Crystallinity

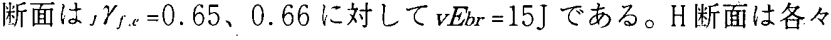
の最低値、平均值、最高值に対して、 ${ }_{H} \gamma_{f, c}=0.94 、 1.06 、 1.15$ 、 $v E b r=68 \mathrm{~J} 、 89 \mathrm{~J} 、 132 \mathrm{~J}$ であり、正の相関がある。また、Crを比べる と $\mathrm{Cr}=66 \% 、 59 \% 、 49 \%$ あり、Cr と ${ }_{H} \gamma_{f, c}$ の間には負の相関があ る。最低値と平均值間を補間すると、 ${ }_{H} \gamma_{f, k} \geqq 1$ となるための条件は $v E b r v E b r \geqq 80 \mathrm{~J} 、 \mathrm{Cr} \leqq 63 \%$ となる。

秋山ら ${ }^{17}$ や中达ら ${ }^{18}$ は、広範な温度領域で実大柱梁接合部の動 的載荷実験を行い、延性破壊一脆性破壊遷移と梁端破壊との関係に ついて、以下の傾向を指摘している。

•脆性破面率 $60 \%$ ～75\%以上、シャルピー值 70J 以下の場合、高 い変形能力ゃ耐力上昇を得にくく、脆性破面が形成されやすい。 このように、既往の破壊実験結果との対応は良好である。 静的に載荷した本実験と文献 15 では、強制冷却により約 $1{ }^{\circ} \mathrm{C}$ に保 持していた。破断直前のサイクルの圧縮予歪 ${ }_{\text {pre }} \varepsilon_{\text {skel }}=0.28 \% \sim 6.30$ $\%$ に対して、温度移行量 $\Delta T_{A}=0.9^{\circ} \mathrm{C} \sim 20.2^{\circ} \mathrm{C}$ と推定した。一方、筆 者は慣性加力装置による実大柱梁接合部の動的載荷実験2゙を行い、 水平ハンチの梁端が実現象として $10^{\circ} \mathrm{C} \sim 20^{\circ} \mathrm{C}$ 上昇し、その発熱に よって遷移温度の移行、すなわち予歪によるシャルピー值の低下は 相殺されていたことを報告している。よって、破壊危険部位のシャ ルピー值が継手耐力に及ぼす影響に関して、発熱がある場合 $v E b r$ を予歪を受ける前の $v E$ と読替えることができると思われる。

以上から、角形鋼管柱一水平ハンチ・変断面梁接合部の最大耐力 は破壊が予想される部分の $v E$ P Cr 考慮した ${ }_{s} \gamma_{f} 、{ }_{H} \gamma_{f}$ を用いて式 (9)、式(10)によりある程度のバラツキはあるがほほ推定できる。

\section{5 梁接合部の変形能力評価}

文献 19）に提唱された塑性変形倍率の評価式(13)、(14) を示す。 $\eta_{i t}=\left(\frac{S-1}{2 S^{2}}\right)\left[\frac{E}{E_{s t}}(S-1)(2 S+1)+3(S+1)\left(\frac{\varepsilon_{p}}{\varepsilon_{y}}\right)\right]$

$\eta_{\lambda}=(1-\lambda)^{3} \eta_{0}$

$S^{-1}=0.2868 \lambda_{f}{ }^{2}+0.0588 \lambda_{w}{ }^{2}+0.7730$ 但し、 $S^{-1} \geqq Y_{f}$

$$
\lambda_{f}=\left(\frac{{ }_{f} \sigma_{y}}{E}\right)^{1 / 2} \cdot \frac{b}{t_{f}} 、 \lambda_{w}=\left(\frac{{ }_{w} \sigma_{v}}{E}\right)^{1 / 2} \cdot \frac{d e}{t_{w}} 、 \mathrm{de}=\mathrm{d} / 2
$$

ここに、 $\sigma_{y}$ : フランジの降伏点、 ${ }_{w} \sigma_{y}:$ ウェブの降伏点、 $E:$ ヤング 係数、 $b:$ フランジ幅の半分、 $d:$ ウェブのせい、 $t_{f}:$ フランジ厚さ、 $t_{w}:$ ウェブ厚さ、 $Y_{f}:$ フランジ材の降伏比である。

$\eta_{\mathrm{o}}$ の (13) 式は補強がない場合、 $\eta_{\lambda}$ の (14) 式は補強がある場合の 評価値である。塑性ヒンジ発生位置から補強部にかけて局部座屈が 生じると仮定した式(13)よりク。算定し、補強部が弾性となり局 部座屈が無補強断面で生じると仮定した式(14)より $\eta_{\lambda}$ 算定し、
Table 5に示す。I A45、I B45、II B45 試験体 6 体では $Q_{u, e}{ }_{J}{ }_{J} Q_{p}$ $=1.02 \sim 1.35$ となり、最大耐力時には、ハンチ先端から柱接合面 （J 断面）に降伏領域が拡大した。よって、II C45 を除く全試験体 12 体は $\eta_{\mathrm{o}}$ で評価すると、 $\eta_{e x} / \eta_{o}=0.07 \sim 0.98$ であり、式(13)の算 定結果よりも小さい值となっていた。これは、梁フランジが局部座 屈が生じる前に破壊したためである。

水平ハンチ・変断面に関して、塑性変形能力が高い順に整理する。 1) 梁端部の形状 II $\eta_{e x /} \eta_{o}=1.15 \sim 1.18$ であり、式(13)によれば、 約 $15 \%$ 安全側の評価となる。柱接合面からハンチ先端までの長さ は梁せいの $56 \%$ あっった。通しダイアフラムの突出部をハンチ形 状にする場合、ウェブの曲げモーメントを柱管壁の面外剛性を期待 しなくても、ダイアフラムとウェブのすみ肉溶接部での降伏せん断 力による偶力に変換して伝達するためには約 $25 \%$ 以上とすれば有 効であるとする文献 8) に示された提唱值の約 2 倍であった。

2) 梁端部の形状 $V \quad \eta_{e x} / \eta_{o}=0.52$ であり、J 断面の梁フランジだけ でなく、柱接合面が降伏した後柱内の組立溶接部から破壊した。ス カラップやフランジ溶接を排除したが、ダイアフラムとフランジが 同厚であり、降伏域が柱に及ぶディテールであると思われる。 3) 梁端部の形状 I ${ }_{J} Q_{p}>_{H} Q_{p}$ となり、塑性ヒンジはフランジ断面積 が大きくなる部分の境界（H断面）で発生するが、 $Q_{u, e}{ }_{J} Q_{p}(2$ 体の 平均值）は $1.03 、 1.11$ となり、柱接合面が降伏した以後の耐力上 昇は少なく、 $\eta_{e x} / \eta_{o}=0.42 \sim 0.52$ であり、低い変形性能であった。 添板をフランジの両側に取付けるだけで完成状態は水平ハンチを設 けた仕口となるが、スカラップ底近傍のフィレット部やハンチ先端 のクレータ処理部の破壊靶性值を改善する必要がある。

4) 梁端部の形状III III B45 試験体は塑性ヒンジ発生位置に混用接 合があり、ボルトがすべった後 $\mathrm{H}$ 断面のフランジ溶接部が破断し た。 $\eta_{e x} / \eta_{o}=0.47 \sim 0.63$ であり、溶接部に歪集中を起こしやすく、 ダイアフラムの出長さを最外縁側のボルトが材軸方向 2 列並びが可 能な長さとする場合、破断を免れることは難しいと思われる。

\section{6. まとめ}

梁端部の形状を実験変数として、JIS- S N 鋼の下限要求勒性値 を有する圧延 H型鋼ならびに大入熱・高パス間温度を作業条件とす る溶接部を用いた角形鋼管柱一水平ハンチ・変断面梁接合部の実験 を行った。以下に、得られた成果をまとめる。

1) 梁材に使用した圧延 $\mathrm{H}$ 形鋼のシャルピー值はフランジの幅の 1 / 4 の位置で50J、フィレットで $16 \mathrm{~J}$ であった。シャルピー值を比較 すると、梁端接合部の靫性は溶接金属、溶接熱影響部、フランジ母 
材、フィレットの順に低く、前 2 者は延性破壊が支配的であり、後 . 2 者は脆性破壊が支配的であった。

2) 水平ハンチ・変断面梁接合部はスカラップを有する場合、従来型 柱梁接合部と同様にスカラップ底のフィレットに裏当て金組立溶接 を重畳させないことを溶接施工上の禁止事項として守られていない 場合は、比較的早期に梁フランジが破断し、変形能力がそしくなる ことが確認された。

3)今回の溶接法では入熱量の大小による変形能力に及ぼす影響を確 認できなかった。梁溶接の中間層だけを高入熱量で溶接しても最終 層の溶接熱作用により材質変化を和らげているためと考えられる。 今後、最終層と中間層について各々の熱影響を検討すべきである。 4)梁端フランジに添板補強のある水平ハンチ梁接合部は、従来型に 比べて降伏耐力・最大耐力が上昇する。しかし、添板を溶接する水 平ハンチ梁接合部は、添板の溶接クレータがハンチ先端で適切に処 理されなかった場合、変形能力が低いことが確認された。クレータ 処理をハンチ先端で行わないようにすべきである。

5) 破面観察から特定した破壊起点近傍の靶性值と梁フランジの継手 効率との関係には、文献15）と16）と同様に、正の相関があること が確認できた。さらに、破壊起点近傍の脆性破面率と梁フランジの 継手効率の関係には負の相関があることが確認できた。

6)角形鋼管柱一水平ハンチ・変断面梁接合部の最大耐力は破壊が予 想される部分のシャルピー值や脆性破面率から求まるフランジの継 手効率 $\gamma_{f} 、{ }_{H} \gamma_{f}$ を用いて、4.3 章式(9) と 5.4 章式(11)、式(12)に よりほほ推定することができる。

今回の研究では、柱梁接合部近傍の温度を $0^{\circ} \mathrm{C} に$ 保持した静的載 荷によるものである。動的負荷による発熱効果や、その温度履歴下 の勒性変化や部材性能の温度依存性を把握できていない。しかし、 6)は梁端部の形状決定のための力学的根拠となるので、実験デー夕 を蓄積し、信頼性を高めていく必要があり、今後の課題としたい。

\section{謝 辞}

この研究は、建設省総合技術開発プロジェクト／次世代鋼材に よる構造物安全性向上技術の開発「接合部・施工と破断」分科会 (主査：森田耕次・千葉大学教授)の一部として行われたものであ る。関係各位に謝意を表する。

\section{参考文献}

1) Bertero, CV.V., Anderson, J.C., and Krawinkler,H.:Performance of steel building structures during the Northridge Earthquake. Rep.No.UBC/EERC94/09, Univ.of California at Berkely, August 1994

2) SAC Joint Venture Guidelines Development Committee:Interim Guidelins Advisory No.1 Evaluation, Repair, Modification and Design of Welded Steel Moment Frames Structures, Rep.No.FEMA-267A, Federal Emergency Management Agency, January 1997

3）日本鋼構造協会:鋼構造の柱梁接合部の設計・施工一兵庫県南部地震の被害を 踏えて、JSSC テクニカルレポート No. 36、ppl-5、pp8-12、1996 年12月 4) B.Kato, K.Morita, Y.Maruoka, H.Sugimoto, M.Teraoka:Seismic Damage of Steel Beam-to-Column Rigid Connections in the 1995 HyogokenNanbu Earthquake -Fabrication-, 2nd International Specialty Conference Stessa'97, pp.811-820, August 1997

5) Egor P.Popov, Toader A.Balan, and Tzong-Shuoh Yang:Post-Northridge Earthquake Seismic Steel Moment Connections,Earthquake Spectra, Volume 14, No.4, November 1998

6) Federal Emergency Management Agency:Recommended Seismic Evaluation and Upgrade Criteria for Existing Welded Steel Moment-Frame Building, FEMA 350, pp.3-1 pp.3-73, July 2000

7) 日本溶接協会：APD 委員会 調査報告 JWES-IS-0001、2000 年 3 月

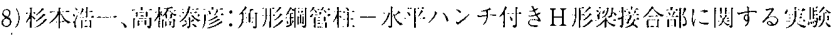

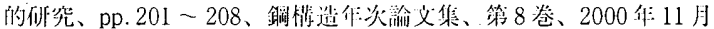

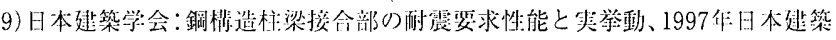
学:会大会 槛造部門 パネルディスカッション資料、pp53-63、1997年:9月

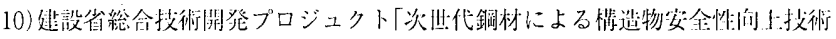

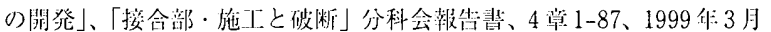

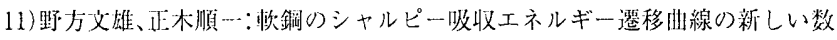
式表示法と破壊䩲性部湖、日本材料治度学会誌、17、pp. 1 - 13、1982年 12) 日本建築学会近畿支部鉄管楧造部会:通しダイアフラム形式で角形鋼管柱に 接合されるH形鋼梁り塑性湾形能力に関する実大実験報告書、1997年 7 月

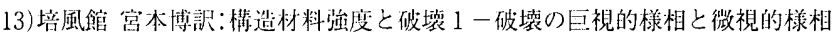
- 、(A.S.Tetelman,A.J.Mcevily,Jr.:Fracture of structure materials) , pp. 80pp. 88、1970年3月

14)森田耕次、汇波戸和正、将橋明之、小南忠義、里見孝之：箱型断面柱のかど 浴接を部分浴込み溶接とした柱はり接合部の力学的挙動に関する破究、日本建築 学会構造系論文集、No. 397、pp48-59、1989 年:3月

15)石井 匠、雨川春三、森田耕次、高梨晃一：通しダイアフラム形式・柱梁接

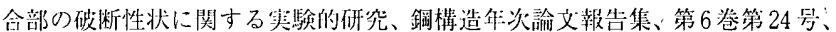
pp87-102、1999年12月

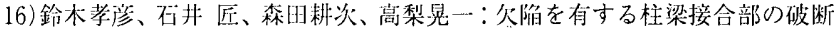
性:状に関する垁験的研究、鋼棈造年次論文報告集、第6巻第 23 号、pp149-164、 1999 年 9 月

17)秋山宏、山田哲、松本由香、松岡三郎、大竹章夫、杉本浩-- : 実大柱梁接 合部の試験温度による延抄破壊一脆性破壞要移、日本建築学会構造系諭文集、 No. $522 、 1999$ 年 8 月

18) 中込忠男、藤本盛久他: $500 \mathrm{~N} / \mathrm{mm}^{2}$ 級鋼の板厚、強度と必要靶性、日本建鹠学 会大会学術講演梗概集、C-1、pp619-620、1995 年8月

19)加藤勉: 柱・梁接合部の耐力、変形能力の改善、鋼構造論文集、第 5 巻第 17 号、pp141-147、1998 年 3 月

20)杉本浩一、高橋泰浐:改良梁端仕口形式を用いた角形鋼管柱ーH形梁接合部 の動的載荷実験(その 4 慣性加力装㖵による耐震性能の調查)、日本建築学会大会 梗概集、2000年 9 月

21) 日本溶接協会鉄鋼部会:建築鉄骨の地震被害と鋼材セミナー(第12回溶接構 造用鋼材に関する斫究発表会)テキスト、1997年6月

\section{付録 1 シャルピー值と脆性破面率の関俰}

シャルピー值 $v E$ は付 1 (a) 式、脆性破面率 $C_{r}$ は付 1(b)式による ${ }^{11)}$ 。

$$
\begin{aligned}
& v E=\frac{\mathrm{vE}_{\text {sheif }}}{\exp \left\{-a \cdot\left(T-\mathrm{vT}_{e}\right)\right\}+1} \quad \ldots-\ldots \text { 付 } 1(\mathrm{a}) \\
& C r=\frac{100}{\exp \left\{-b \cdot\left(T-v T_{r s}\right)\right\}+1}-\ldots-\text { - 付 } 1(\mathrm{~b})
\end{aligned}
$$

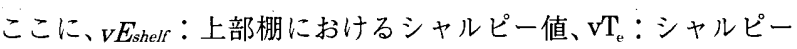
值遷移温度、 $\mathrm{vT}_{\mathrm{r}}$ : 脆性破面遷移温度である。 付 1 (a) と付 1 (b) から温度 $T$ を消去すると、

$$
C r=\frac{100}{\exp \left(b / a \cdot \ln \left(\mathrm{vE}_{\mathrm{shelf}} / v E-1\right)+b \cdot\left(\mathrm{vT}_{\mathrm{rs}}-\mathrm{vT}_{\mathrm{e}}\right)\right)+1}-- \text { 付 } 1(\mathrm{c})
$$

となる。

\section{付録 2 破數起点近傍の破断直前の推定シャルピー值}

鋼材は繰返しの塑性歪によって勒性が低下することが知られて おり、繰返し載荷による勒性の低下を考慮して、破断に至った一 方向載荷の開始前までに蓄積された破壊起点近傍の歪を予歪と定 義し、破断発生前の破壊起点部での勒性值の推定 ${ }^{21)}$ を行った。 SM 490A 材を対象に行った予歪材のシャルピー衝撃試験の結果、 シャルピー値の低下量を遷移温度 $v T_{e}$ の温度下降量 $\Delta T_{A}$ と評価した 場合、歪骨格曲線で求めた予歪量 $p r e \varepsilon_{\text {skel }}$ と $\Delta T_{A}$ との関係は次の関係 式で整理できると報告している。

$$
\begin{aligned}
& \Delta T_{A}=3.2{ }_{p r e} \varepsilon_{\text {skel }} \quad \ldots-\ldots \text { 付 } 2(\mathrm{a}) \\
& \dot{v} E_{b r}=\frac{\mathrm{vE}_{\text {shelf }}}{\exp \left\{-a \cdot\left(T-\mathrm{vT}_{\mathrm{e}}-\Delta T_{A}\right)\right\}+1}-\ldots-\text { 付 } 2(\mathrm{~b})
\end{aligned}
$$

ここに、 $\Delta T_{A}$ : 予歪による遷移曲線上の温度下降推定值 $\left({ }^{\circ} \mathrm{C}\right)$ 、 $p r e \mathcal{E}_{s k e l}$ : 歪骨格曲線から求めた圧縮予歪量 $(\%) 、 v E b r$ : 破断直前の 推定シャルピー值である。

（2001年 6 月 8 日原稿受理，2001年11月 8 日採用決定 $)$ 